\title{
An ANALYSis OF CURING OF EPOXY RESIN by STEADY-STATE FLUORESCENCE SPECTROSCOPY AND DETERMINATION OF A STORAGE TEMPERATURE
}

\author{
Michaela Mikulicova \& Vojtech Kresalek
}
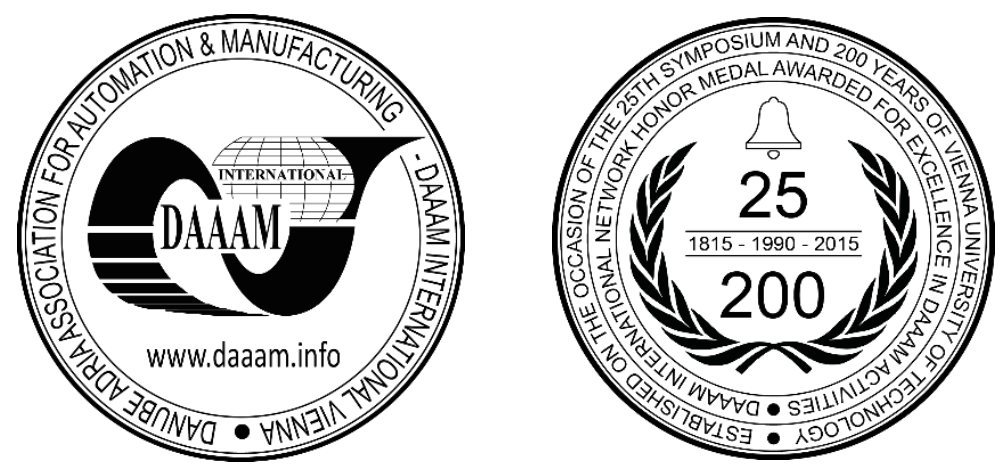

This Publication has to be referred as: Mikulicova, M[ichaela] \& Kresalek, V[ojtech] (2018). An Analysis of Curing of Epoxy Resin by Steady-State Fluorescence Spectroscopy and Determination of a Storage Temperature, Proceedings of the 29th DAAAM International Symposium, pp.1135-1138, B. Katalinic (Ed.), Published by DAAAM International, ISBN 978-3-902734-20-4, ISSN 1726-9679, Vienna, Austria

DOI: $10.2507 / 29$ th.daaam.proceedings. 162

\begin{abstract}
In this paper, steady-state fluorescence spectroscopy is used to analyse the curing of epoxy resin. The analysed mixture of epoxy resin EPOXY 1200 and hardener P11 is measured at seven different temperatures: at room temperature $\left(23^{\circ} \mathrm{C}\right)$, at the lower temperature $\left(9{ }^{\circ} \mathrm{C}\right)$ and at the higher temperatures $\left(30{ }^{\circ} \mathrm{C}, 40{ }^{\circ} \mathrm{C}, 50{ }^{\circ} \mathrm{C}, 70{ }^{\circ} \mathrm{C}\right.$ and $\left.80{ }^{\circ} \mathrm{C}\right)$. The results demonstrate that the process of curing of epoxy resin accelerates with increasing temperature. The measured data are further processed to determine a storage temperature. The appropriate storage temperature for the analysed mixture is stated as $4{ }^{\circ} \mathrm{C}$ or less.
\end{abstract}

Keywords: fluorescence spectroscopy; epoxy resin; curing; storage temperature

\section{Introduction}

Epoxy resins are versatile polymers with a wide range of applications in various fields [1], [2], [3], [4], [5]. Materials based on epoxies are very strong, flexible and have good electrical properties. Therefore, epoxies can be used as adhesives, paints, laminates, in automotive, aviation and shipping industry [2], [4], in electrotechnics [1], [2], [6], in dentistry [7], in optoelectronics [8]. An important property of the resin is a curing after application. Hardeners are used for curing. Hardeners are chemicals that react with epoxy groups to form a solid three-dimensional network [2]. To improve the quality of the epoxies, nanoparticles with different characteristics [9], [10], [11], [12] or dyes [8] can be added to the mixture.

The process of curing of epoxy resin is substantial for the quality of the resulting material [5], [13]. In order to achieve the required properties, the curing must take place under the optimum conditions given for the used material or mixture. The curing of resin can be investigated by various methods [1], [2], [3], [14]. The most commonly used methods include nuclear magnetic resonance, viscosity measurement, dielectric spectroscopy and Raman spectroscopy [4], [9], [13]. However, the present research is focused not only on the process of curing. To investigate epoxy properties which depend on composition, the spectroscopic methods NIR and MIR [14], [15] or UV-VIS and FTIR [16] are also used. 
Another research is focused on material degradation or ageing. This research uses methods such as electroluminescence [1], [6], [11] and chemiluminescence [11], [17].

In this paper, steady-state fluorescence spectroscopy is used to analyse the curing of epoxy resin. Fluorescence spectroscopy is a simple, fast and sensitive method for analysing organic and inorganic substances. Moreover, it is noninvasive. Due to this, fluorescence spectroscopy is widely used in many scientific disciplines such as chemistry, biochemistry, environmental chemistry, forensic analysis and food industry.

The advantage of fluorescence spectroscopy for analysing the curing of epoxy resin is the simplicity of analysis with negligible influence on the process of curing or on the resin itself. In addition, measurement is contactless. The purpose of this paper is to demonstrate the usability of steady-state fluorescence spectroscopy to analyse the curing of epoxy resin and to determine the storage temperature of investigated resin using the measured data.

\section{Instrumentation and Samples}

The curing of epoxy resin was analysed by steady-state fluorescence spectroscopy. Emission spectra were obtained by an ISS PC1 spectrofluorometer which uses $300 \mathrm{~W}$ high-pressure xenon arc lamp as a source of excitation light and photomultiplier in photon counting mode as a detector. The measurement was performed using optical fibre pulled out of the instrument.

After a series of experiments, a suitable excitation wavelength was set to $260 \mathrm{~nm}$. Epoxy resin EPOXY 1200 was mixed with hardener P11 in a ratio of 100:6.5. The thin layer of the resulting mixture was measured at room temperature $\left(23{ }^{\circ} \mathrm{C}\right)$ for 24 hours. The sample was measured every 15 minutes. Subsequently, the measurements were repeated for samples cured at temperatures of $9{ }^{\circ} \mathrm{C}, 30{ }^{\circ} \mathrm{C}, 40{ }^{\circ} \mathrm{C}, 50{ }^{\circ} \mathrm{C}, 70{ }^{\circ} \mathrm{C}$ and $80{ }^{\circ} \mathrm{C}$.

\section{Results}

The aim of the experiment was to prove the usability of steady-state fluorescence spectroscopy to analyse the curing of epoxy resin and to determine a storage temperature of the investigated resin. For this purpose, the mixture of epoxy resin EPOXY 1200 and hardener P11 was analysed.

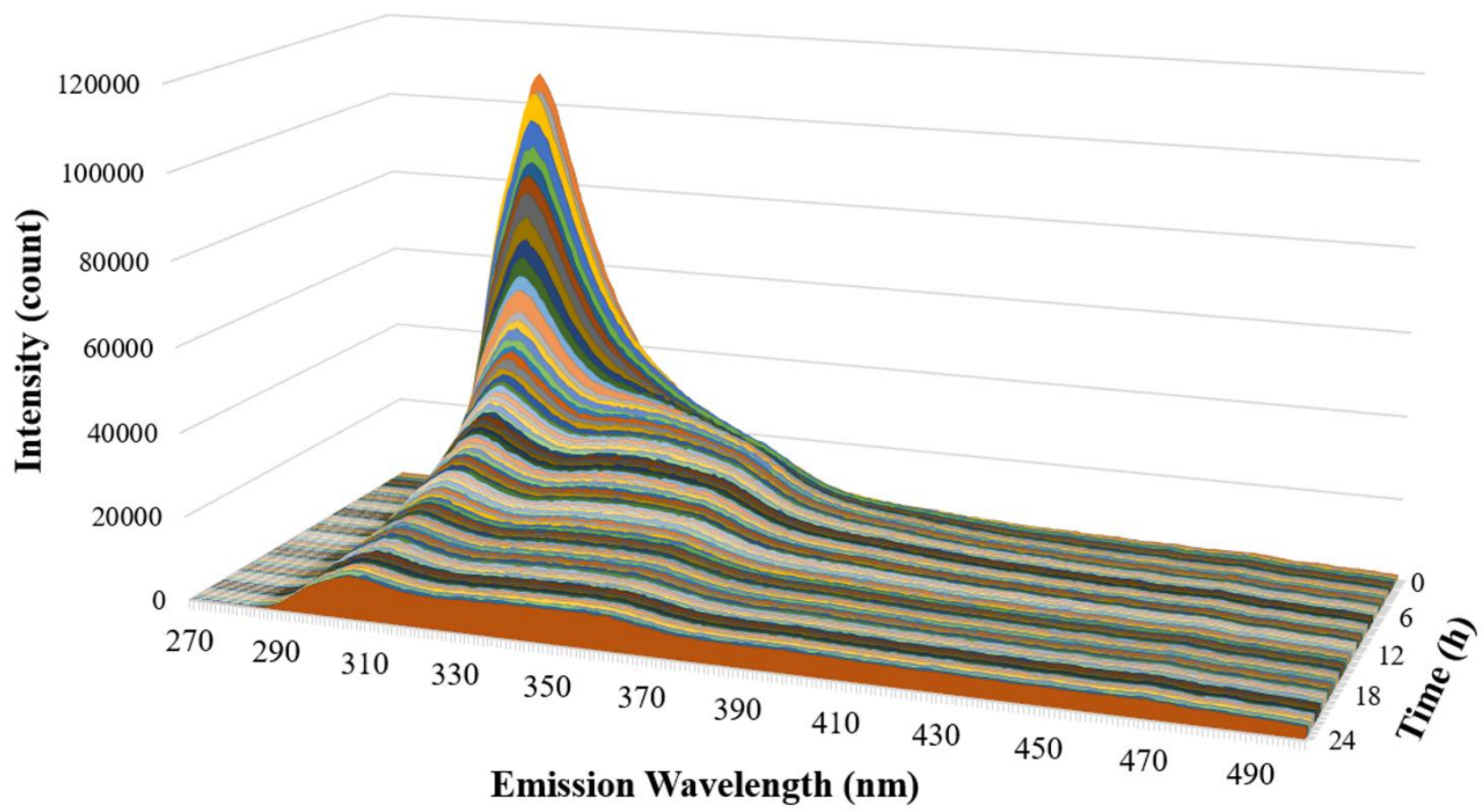

Fig. 1. Emission spectra of epoxy resin measured at room temperature $\left(23^{\circ} \mathrm{C}\right)$ for 24 hours

Fig. 1 presents the emission spectra of resin measured at room temperature $\left(23^{\circ} \mathrm{C}\right)$ for 24 hours. As can be seen, after the initial fast decrease, the intensity of fluorescence decreased gradually. Then, in the last ten hours, a slightly decreasing trend was observed. This indicates that the process of curing decelerates with time.

It is worthwhile to note that resin was cured after 24 hours which was verified by the measurement after 48 hours. The emission spectra of resin measured at $9{ }^{\circ} \mathrm{C}, 30^{\circ} \mathrm{C}, 40{ }^{\circ} \mathrm{C}, 50{ }^{\circ} \mathrm{C}, 70^{\circ} \mathrm{C}$ and $80{ }^{\circ} \mathrm{C}$ were obtained in the same way. 


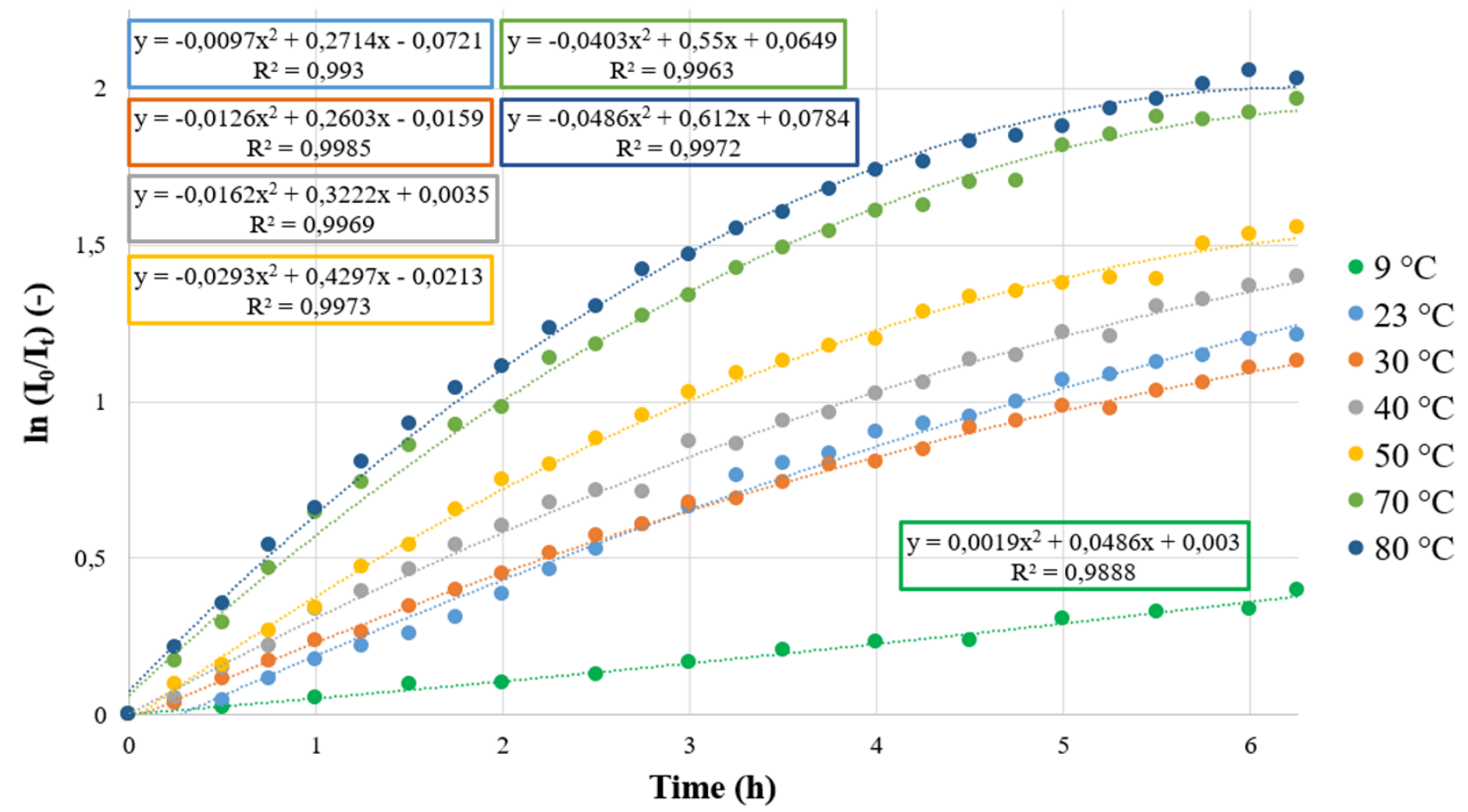

Fig. 2. Velocities of curing for individual temperatures and their polynomial functions

To analyse the velocity of curing, the peak at $307 \mathrm{~nm}$ was chosen for further analysis. The intensity in time $t=0 \mathrm{~h}$ was marked as $I_{0}$, the intensities measured during the process of curing were marked as $I_{t}$. Then, all intensities were converted into the new form (1). Time dependencies of these converted intensities are illustrated in Fig. 2. As can be seen, the process of curing of epoxy resin accelerates with increasing temperature. The velocities of this process are characterized by appropriate polynomial functions which correspond to the temperatures.

$$
\mathrm{y}=\ln \frac{I_{0}}{I_{t}}(-)
$$

These polynomial functions were further processed to determine a storage temperature. Constants $k_{0}$ of all linear polynomials were connected to the relevant temperatures. As a result, the temperature dependency of $k_{0}$ was obtained. Then a polynomial trendline was fitted to the data. This trendline intersects temperature axis in the value $4{ }^{\circ} \mathrm{C}$, as shown in Fig. 3. Obtained results mean that the crosslinking reaction of resin stops at the temperature of $4{ }^{\circ} \mathrm{C}$. Due to this, the appropriate storage temperature for the analysed epoxy resin mixture is stated as $4{ }^{\circ} \mathrm{C}$ or less.

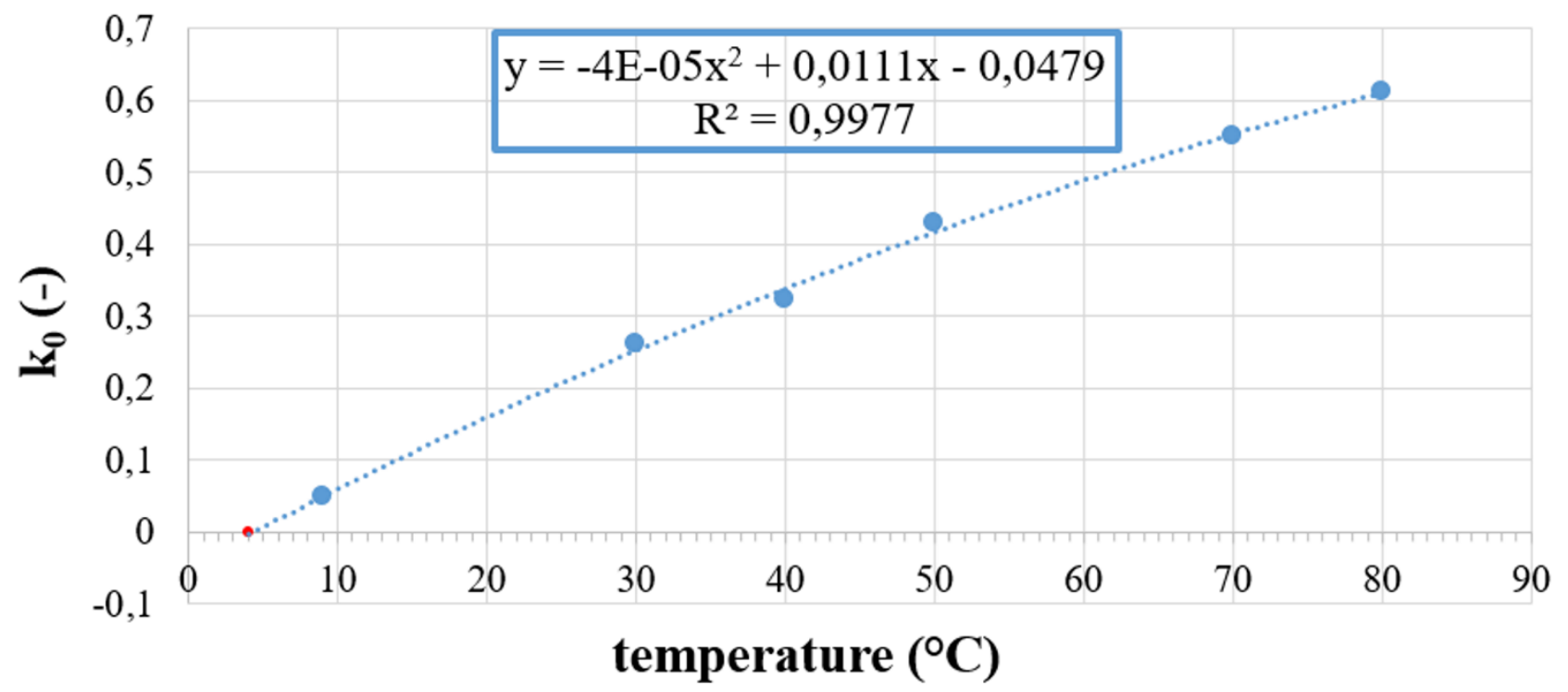

Fig. 3. Temperature dependency of $k_{0}$ and stated storage temperature (red dot) 


\section{Conclusion}

Steady-state fluorescence spectroscopy was used to analyse the curing of epoxy resin EPOXY 1200 mixed with hardener P11. The given results indicate that the process of curing of epoxy resin decelerates with time. The dependence of curing velocity on temperature was also demonstrated. It was found that the process of curing accelerates with increasing temperature. Finally, the measured data were processed to determine a storage temperature. This temperature was stated as $4{ }^{\circ} \mathrm{C}$ or less because crosslinking reaction of resin stops at this temperature. Overall, curing of epoxy resins can be analysed by steady-state fluorescence spectroscopy. However, it should be borne in mind that this method provides no information about resin compounds which have no fluorescence properties. One of the challenges for future research is to test different kinds of resin and describe their behaviour with a mathematical model.

\section{Acknowledgments}

This work was supported by the Internal Grant Agency of Tomas Bata University under the project No. IGA/FAI/2018/014.

\section{References}

[1] Gallot-lavallée, O., Teyssedre, G., Laurent, C. \& Rowe, S. (2005). Identification of photoluminescence features of an epoxy resin based on components features and curing effects, Polymer, Vol. 46, No. 8, 2005, pp. 2722-2731., DOI: 10.1016/j.polymer.2005.02.003

[2] Janošová, M. (2011). Curing of epoxy systems, Diploma thesis, Department of Technology, Thomas Bata University, Zlín, Czech Republic

Janošová, M. (2011). Vytvrzování epoxidových systémů, Diplomová práce, Fakulta technologická, Univerzita Tomáše Bati, Zlín

[3] Lange, J., Ekelöf, R. \& George, G. A. (1999). Charge-recombination luminescence as a monitor of network formation during cure of epoxy resins, Polymer, Vol. 40, No. 1, 1999, pp. 149-155., DOI: 10.1016/S00323861(98)00227-4

[4] Lyon, R. E., Chike, K. E. \& Angel, S. M. (1994). In Situ Cure monitoring of Epoxy Resins Using Fiber-Optic Raman Spectroscopy, Journal of Applied Polymer Science, Vol. 53, No. 13, 1994, pp. 1805-1812., DOI: 10.1002/app.1994.070531310

[5] Sewell, G. J., Billingham, N. C., Kozielski, K. A. \& George, G. A. (2000). Charge recombination luminescence from epoxy resins Part. 1. Correlation of luminescence with cure, Polymer, Vol. 41, No. 6, 2000, pp. 2113-2120., DOI 10.1016/S0032-3861(99)00381-X

[6] Griseri, V., Dissado, L. A., Fothergill, J. C., Laurent, C. \& Teyssèdre. (2001). Photoluminescence, recombination induced luminescence and electroluminescence in epoxy resin, Journal of Physics D: Applied Physics, Vol. 34, No. 16, 2001, pp. 2534-2540., DOI: 10.1088/0022-3727/34/16/320

[7] Ivanisevic, A., Lainovic, T., Blazic, L. \& Vilotic, M. (2014). Influence of Light-Curing Mode on the Mechanical Properties of Dental Resin Nanocomposites, Procedia Engineering, Vol. 69, 2014, pp. 921-930., DOI: 10.1016/j.proeng.2014.03.071

[8] Eronen, A., Harju, A., Mutanen, J., Lajunen, H., Suvanto, M., Pakkanen, T. \& Kuittinen, M. (2015). Micropatterned luminescent optical epoxies, Optics Express, Vol. 23, No. 26, 2015, pp. 33419-33425., DOI: 10.1364/OE.23.033419

[9] Cividanes, L. S., Brunelli, D. D., Antunes, E. F., Corat, E. J., Sakane, K. K. \& Thim, G. P. (2013). Cure Study of Epoxy Resin Reinforced with Multiwalled Carbon Nanotubes by Raman and Luminiscence Spectroscopy. Journal of Applied Polymer Science, Vol. 130, No. 1, 2013, pp. 544-553, DOI: 10.1002/APP.37815

[10] Cividanes, L. S., Simonetti, E. A.N., Moraes, M. B., Fernandes, F. W. \& Thim, G. P. (2014). Influence of Carbon Nanotubes on Epoxy Resin Cure Reaction Using Different Techniques: A Comprehensive Review, Polymer Engineering and Science, Vol. 54, No. 11, 2014, pp. 2461-2469., DOI: 10.1002/pen

[11] Guo, W., Zhang, A., Zhang, X., Huang, Ch., Yang, D. \& Jia, N. (2016). Multiwalled carbon nanotubes/gold nanocomposites-based electrochemiluminiscent sensor for sensitive determinantion of bisphenol A, Analytical and Bioanalytical Chemistry, Vol. 408, No. 25, 2016, pp. 7173-7180., DOI: 10.1007/s00216-016-9746-y

[12] Ropus, I[vana]; Carcia, G[ianluca]; Giorcelli, M[auro]; Tagliaferro, A[lberto]; Haramina, T[atjana] \& Curkovic, L[idija] (2016). Mechanical Properties of Epoxy/Multi-Walled Carbon Nanotubes Composites, Proceedings of the 26th DAAAM International Symposium, pp.0940-0947, B. Katalinic (Ed.), Published by DAAAM International, ISBN 978-3-902734-07-5, ISSN 1726-9679, Vienna, Austria DOI: $10.2507 / 26$ th.daaam.proceedings.132

[13] Younes, M., Wartewig, S., Lellinger, D., Strehmel, B. \& Strehmel, V. (1994). The curing of epoxy resins as studied by various methods", Polymer, Vol. 35, No. 24, 1994, pp. 5269-5278., DOI 10.1016/0032-3861(94)90479-0

[14] Poisson, N., Lachenal, G. \& Sautereau, H. (1996). Near- and mid-infrared spectroscopy studies of an epoxy reactive system, Vibrational Spectroscopy, Vol. 12, No. 2, 1996, pp. 237-247., DOI: 10.1016/0924-2031(96)00027-6

[15] Rigail-Cedeño, A. \& Sung, Ch. S. P. (2005). Fluorescence and IR characterization of epoxy cured with aliphatic amines, Polymer, Vol. 46, No. 22, 2005, pp. 9378-9384., DOI: 10.1016/j.polymer.2005.04.063

[16] Xu, Y. E. \& Sung, Ch. S. P.. (2002). UV, Luminescence, and FTIR Characterization of Cure Reaction in Bisphenol A Dicyanate Ester Resin, Macromolecules, Vol. 35, No. 24, 2002, pp. 9044-9048., DOI: 10.1021/ma020589h

[17] Suzuki, T., Sunose, T., Amasaki, I. \& Ozawa, T.. (2002). Chemiluminescence of epoxy resin, Polymer Degradation and Stability, Vol. 77, No. 1, 2002, pp. 87-91., DOI: 10.1016/S0141-3910(02)00082-4 